\title{
Analyzing the Effect of Entrepreneurial Characteristics to Maximize the Architectural Design Quality Value in Greater Amman Municipality (Case Study)
}

\author{
Mohammad Izzat Alhalalmeh ${ }^{1}$, Neameh Abbas Al-khafaj ${ }^{2} \&$ Feras Suliman Al shalabi ${ }^{3}$ \\ ${ }^{1}$ Business Administration, Al-Balqa Applied University, Princess Alia University College, Jordan \\ ${ }^{2}$ Strategic Management, Faculty of Business, Business Administration Department, Al Isra. University, Jordan \\ ${ }^{3}$ Business Administration, Al-Balqa Applied University, Amman University College, Jordan \\ Correspondence: Mohammad Izzat Alhalalmeh, Business Administration, Al-Balqa Applied University, Princess \\ Alia University College, Jordan. E-mail: dr.alhalalmeh@bau.edu.jo
}

Received: December 29, 2017

doi:10.5539/ijbm.v13n4p219
Accepted: February 7, 2018

Online Published: March 18, 2018

URL: https://doi.org/10.5539/ijbm.v13n4p219

\begin{abstract}
The study aims to analyze the impact of entrepreneurial characteristics represented in (the need for achievement, self-confidence, take the initiative, independence, responsibility, willingness to take risks, and experience) to maximize the architectural design quality value related to (the value of the design interest in the environment changes - durability -, good interior design - benefit - and the aesthetic design). The hypotheses have been tested by adopting answers from engineers working in the Greater Amman Municipality, (250 engineers), using the multiple linear regression analysis. The study finds that the entrepreneurial characteristics represented in (the need for achievement, self-confidence, take the initiative, independence, responsibility, the willingness to take risks, and experience) have an impact on the value of architectural design quality in general and on its sub-value in particular. This demonstrates that maximizing the architectural design quality value depends on analyzing the impact of entrepreneurial characteristics of engineers partially.
\end{abstract}

Keywords: entrepreneurial characteristics- architectural design quality value

\section{Introduction}

Entrepreneurs are one of the public and private organizations' factors of success. This success depends on the entrepreneurs' possession of characteristics that distinguish them from others. These characteristics enable entrepreneurs to achieve distinguished results. Most of these results are related to the inclusive quality, among which is the architectural design quality. The architectural design quality value is the criteria to choose projects, especially those related to architectural design.

The entrepreneurial characteristics were subject to study and analysis in the fields of economy, finances, accounting, international business, operations, marketing, information technology and behavior. These characteristics were dissimilar in the degree of focused it in the entrepreneurial human recourse in general and in the engineering specializations in particular.

Moreover, there was a dissimilar focus on the architectural design quality in the significance and value of its components by researcher's andadvisories in the field of organizations' business quality in different related specialties, as a try to define the value of architectural design quality.

This study aims to analyze the impact of entrepreneurialcharacteristics to maximize the architectural quality value depending on a questionnaire distributed among engineers work in projects management departments in entities subject to Greater Amman Municipality, Jordan. To achieve this goal, the study consists of the following:

- Study methodology.

- Previous studies.

- Results.

- Results discussion. 
- Conclusions and recommendations.

\section{Previous Studies}

The study of Sultan (2011) aimed to recognize the availability of entrepreneurial characteristics and their relation with some personal changes. Applied study on business administration bachelor Students at the University of South West Bank. The study also aimed to recognize the students' needs to undertake the entrepreneurial work. The study used the descriptive analytical approach and a questionnaire as a tool to collect data. The study found that the entrepreneurial characteristics are highly available in the study sample, according to the following order: planning, self-control, self-confidence, a high level of energy and commitment, communication with others, independency, taking risks, and the need for achievement. The study also showed that there are no differences in the availability of entrepreneurial characteristics that can be attributed to gender, university marks, high school diploma and school youth leadership programs, while there are differences due to the university variable.

The study of Al-Umari\&Nasir (2011) aimed to measure the entrepreneurship characteristics for post graduate students in business administration and their Impact on entrepreneurship, a comparative study between Amman Arab University and Damascus University. The study used a questionnaire distributed over the study sample (115) students of master and PhD studies for the year (2009-2010). The study concluded that there is a positive relation between the entrepreneurial characteristics of the post-graduation students in business administration in Amman and Damascus universities, and entrepreneurship. It also concluded that there is a statistically significance effect of the entrepreneurial characteristics in entrepreneurship, also there is a variance of statistical significance between the post-graduate students in business administration in Amman and Damascus universities in the entrepreneurship and the entrepreneurship behavior.

The study of (Olawale and Francis, 2011) aimed to recognize the effect of firm and entrepreneurial characteristics on access to debt finance through small and medium businesses in South Africa. Data has been collected through a questionnaire. The analytical statistics included the descriptive analysis, Pearson correlation coefficient and linear regression. The results showed that the entrepreneurial characteristics affect the access to debt finance through small and medium businesses.

The study of (Khalid and Mohammad, 2013) aimed to recognize the entrepreneurial characteristics of university students. It also aimed to test the relation between their entrepreneurial characteristics and the tendency to take initiatives using the techniques of multiple variables. The study population was made of students in their last year of different specialties in engineering, economy and information technology in the Islamic University in Ghaza. The study used a random sample, made of (451) members. The descriptive analysis results showed that students tend to entrepreneurship and that (24.1\%) of the sample have an entrepreneurial tendency. The results showed as well that there are six entrepreneurial characteristics; two of them only have an effect on the students' orientation for entrepreneurship, which are independency and self-control.

The study of (Kamal and Sathiyakala, 2013) aimed to evaluate the effect of entrepreneurial characteristics on the organizational development. To measure the entrepreneurial characteristics, the efficiency of accomplishment, efficient planning and efficient authority have been chosen as independent variables. Their effect on the entrepreneurial characteristics has been measured through a random sample of (105) business men from Candi region. The regression and correlation coefficients have been used to know the contribution of each variable. The results of the correlation showed that small business entrepreneurs in Candi have a significance relation with organizational development. According to the regression model, the contribution of the efficiency of accomplishment and efficient authority was low whereas the contribution of the efficient planning was relatively high. The study concluded that the entrepreneurial characteristics have highly affected the organizational development.

The study of (Jarrar, 2013) aimed to measure the impact of architectural design quality in achieving the competitive advantage through an exploratory study over a sample of consulting engineering companies in Amman, Jordan. To achieve this, the researcher used the descriptive analytical approach. The study sample consisted of CEOs and architecture engineers in (30) consulting companies. The researcher used a questionnaire about the architectural design quality dimensions (good interior design (benefit), the design interest in the environment changes (durability) and the aesthetic design) and the competitive advantage dimensions (low cost, excellence and creativity). Data has been analyzed using the descriptive deductive analysis. The results showed that there is an effect of statistical significance for the architectural design quality dimensions on achieving the competitive advantage dimensions. The study also emphasized the importance of awareness toward this effect which is the base to achieve the added value for the company.

The study of (AbdAlwahab, 2015) aimed to measure the effect of entrepreneurs on the success of small business 
in the medical equipment supply organizations in Jordan through its independent variable; the entrepreneurs' characteristics dimensions (the need for achievement, self-confidence, take the initiative, independence and responsibility, willingness to take risks, and experience) and the dependent variable of small business success with its dimensions (sales increment, total revenues growth, capital growth through revenues and work expansion). The study followed the descriptive analytical approach. The study sample is made of owners and managers of small businesses in the area of medical equipment in Jordan (66) companies. The study data was collected through a questionnaire. The study results showed that the entrepreneurial characteristics are highly available by the small businesses owners except for willingness to take risks. It also indicates that there is an effect of entrepreneurs on the success of small business. The study most important conclusion was conducting training courses for small businesses owners and managers in the field of medical equipment in order to develop the entrepreneurs' characteristics emphasizing the dimension of willingness to take risks.

The study of Afifi and others (2016) aimed to develop the educational design quality standards for e-learning courses at Dammam University. The study defined (9) areas for the educational design quality for e-learning courses. It also defined a list of the educational design quality standards, it includes ten general standards and(20) subsidiary standards; moreover, (170) performance indicators that measure the achievement of these standards. A gradual scale has been designed to evaluate the educational design quality for e-learning courses.

The study of Qais (2013) aimed to reveal the effect of entrepreneurial characteristics on the organizational commitment over a sample of CEOs in the Public Company for Electrical Industries in Diala. The study was based on the criterion of entrepreneurial characteristics and the organizational commitment criterion. The study sample was made of (62) members. The study concluded that the level of entrepreneurial characteristics for the chosen sample in the chosen field was medium. And the level of the managers" organizational commitment was medium as well. The study also concluded the weak effect of the entrepreneurial characteristics on the organizational commitment in the study sample.

\section{Study Methodology}

\subsection{Study Problem}

The overall quality is one of the critical success factors for the Greater Amman Municipality. Maximizing the architectural design quality is one of the active aspects that distinguish the Municipality's operations in a sustainable way concerning the economic, environmental and social dimensions. The applied studies in this area are limited. Add to this, the rareness of the studies that focus on defining the entrepreneurial characteristics of the engineers that work in the municipality departments. Moreover, the lack of knowledge and applications reveal the need to analyze the strength and the impact of entrepreneurial characteristics in maximizing the architectural quality value. The core ideas of this study are determined by the previous studies such as, Jarrar (2013), and Abdelwahab (2015). To recognize the level of interest being paid for both and to analyze their effect, the study problem can be defined through the following questions:

1- What is the level of entrepreneurial characteristics for engineers in Greater Amman Municipality?

$2-$ What is the level of architectural design quality value in Greater Amman Municipality?

3 - Is there an effect of the entrepreneurial characteristics over the architectural design value?

\subsection{The Importance of the Study}

1- The rareness of studies that focus on analyzing the effect of entrepreneurial characteristics in maximizing the architectural design quality in Greater Amman municipality as being one of the active entities in Jordan.

2- The need to provide a deep practical knowledge about the distinguished entrepreneurial characteristics of human resources in the engineering specialties as for they are considered the factor that achieves the economic, environmental and social sustainability.

3- The active role of the architectural design quality value in showing the urban planning project results executed by the Greater Amman Municipality departments.

4- The need to draw the attention of quality and entrepreneurship specialists to the importance of studying and analyzing the entrepreneurial characteristics and the architectural design quality to enrich the knowledge in both fields in a unique mutual way.

\subsection{Study Objectives}

1- Identifying the entrepreneurial characteristics for engineers in Greater Amman Municipality.

2- Identifying the value of architectural design quality in Greater Amman Municipality. 
3- Analyzing the impact of entrepreneurial characteristics in maximizing the architectural design quality value.

\subsection{Study Approach}

The descriptive approach (method)was used to determine the level of engineers' concern toward the entrepreneurial characteristics and the architectural design quality value in the Greater Amman Municipality's projects, its departments and its directorates.

The results of arithmetic average and the standard deviation of these two dimensions were the base of this description, besides; using the analytical approach (method) to verify the impact of entrepreneurial characteristics in maximizing the architectural design quality value totally or partially. The multiple linear regression analysis has been used to check the validity of the idea's experiment and application.

\subsection{Study Population and Sample}

The engineers of Greater Amman Municipality, its departments and its directorates have been chosen to be the study population (target group). The study sample consists of (250) engineers of different specialties, known by their entrepreneurial minds and their remarkable qualifications that distinguish them from other workers in the municipality. They are the human capital and the source of creativity and development, besides having the ability to deal with different business problems and their results.

\section{Hypotheses}

Based on the study we formed the following hypotheses:

The Main Hypothesis:

There is no effect of statistical significance with a value of $(\alpha=0.05)$ for the entrepreneurial characteristics on the architectural design quality value.

The first sub-hypothesis:

There is no effect of statistical significance with a value of $(\alpha=0.05)$ for the entrepreneurial characteristics on the value of the design interest in the environment changes (durability).

The second sub-hypothesis:

There is no effect of statistical significance with a value of $(\alpha=0.05)$ for the entrepreneurial characteristics on the value of good interior design (benefit).

The third sub-hypothesis:

There is no effect of statistical significance with a value of $(\alpha=0.05)$ for the entrepreneurial characteristics on the value of the aesthetic design.

\subsection{Study Tool}

The questionnaire; the study tool, consists of several items to measure the entrepreneurial characteristics taking advantage of the study of (Abd Al-Wahab, 2014). Using the study of (Jrrar, 2013) we could measure the value of architectural design quality. The questionnaire items were classified according to the study's two variables as it is shown in table (1):

Table 1. The dimensions of the entrepreneurial characteristics and the architectural design quality value

\begin{tabular}{ll}
\hline The study two variables' dimensions & Reference \\
\hline Entrepreneurial characteristics & \\
The need for achievement & \\
Self-confidence & \\
Take the initiative & (Abd Al-Wahab, 2015) \\
Independence and responsibility & \\
Willingness to take risks & \\
Experience & \\
Architectural design quality value & (Jarrar, 2013) \\
The design interest in the environment changes (durability) & \\
Good interior design (benefit) & \\
Aesthetic design &
\end{tabular}




\subsection{Study Tool Validity}

The validity of the study tool has been tested through showing it to a group of members in the Jordanian Universities, specialized in management and applied statistics in order to know their opinions and benefit from their experiences. This was to test the items linguistic relevance and their connection with the dimensions of entrepreneurial characteristics and architectural design quality value. The items have been modified and edited according to the referees' opinions. Six experts from different departments and directorates in Greater Amman Municipality (the study population) have been consulted to be sure about the study tool relevance with engineering business nature. A linguistic check has been applied on the questionnaire as well.

\subsection{Study Tool Reliability}

Cronbach's alpha coefficient has been used to calculate the reliability coefficients of the study variables (measuring the internal consistency of the questionnaire items). Cronbach's alpha coefficient values for all the study variables' dimensions and for the study tool as a whole were acceptable, as they are shown in table (2).The values were between $(0.85-0.92)$ for the entrepreneurial characteristics and (0.82-0.84) for the architectural design quality value. By this, it is over the standard value of $(0.60)$, which means that these measurements have a great level of internal consistency, reliability and acceptance.

Table 2. Cronbach's alpha coefficient values/ the study tool consistency (The internal consistency of the questionnaire articles)

\begin{tabular}{lll}
\hline Main Variables & Sub-variables & Cronbach's alpha \\
\hline & Entrepreneurial Characteristics & 0.96 \\
& The need for achievement & 0.89 \\
Entrepreneurial & Self-confidence & 0.85 \\
Characteristics & Take the initiative & 0.87 \\
& Independence and responsibility & 0.87 \\
& Willingness to take risks & 0.90 \\
& Experience & 0.92 \\
Architectural design & quality & 90 \\
value & Architectural design quality value as a whole & 0.84 \\
& (durability) & 0.82 \\
& Good interior design (benefit) & 0.82 \\
\hline
\end{tabular}

\subsection{The Study Results}

The descriptive questions can be answered depending on the values of the arithmetic average and standard deviation of the sample's engineers regarding the study two variables, whereas the conferential question and hypotheses will be answered and will define their statistical significance through the results of Multiple Linea Regression analysis.

4.4.1 The Level of Interest in the Entrepreneurial Characteristics

Table (3) shows the values of arithmetic average and the priority order of entrepreneurial characteristics.

Table 3. The values of arithmetic average and standard deviation, and the priority order of entrepreneurial characteristics $(\mathrm{N}=250)$

\begin{tabular}{lllll}
\hline $\begin{array}{l}\text { Entrepreneurial } \\
\text { characteristics }\end{array}$ & Arithmetic average & $\begin{array}{l}\text { Standard } \\
\text { deviation }\end{array}$ & Relative importance & $\begin{array}{l}\text { Dimensions } \\
\text { order }\end{array}$ \\
\hline The need for achievement & 4.46 & 0.572 & 0.89 & Third \\
Self-confidence & 4.37 & 0.579 & 0.87 & Fifth \\
Take the initiative & 4.51 & 0.527 & 0.90 & First \\
Independence and responsibility & 4.49 & 0.530 & 0.90 & Second \\
Willingness to take risks & 4.44 & 0.597 & 0.89 & Fourth \\
Experience & 4.36 & 0.637 & 0.87 & Sixth \\
\hline
\end{tabular}


The results related to the entrepreneurial characteristics were as the following: Take the initiative was in the first place in priority followed by independence and responsibility in the second place. The dimension of the need for achievement was in the third place whereas the dimension of willingness to take risks was in the fourth place. Self-confidence was in the fifth place and the dimension of experience came in the last place. The values of arithmetic average were above the standard mean (3) with low convergent values for the standard deviation.

\subsubsection{The Architectural Design Quality Value}

Table (4) shows the values of arithmetic average and standard deviation, and the priority order of architectural design quality value.

Table 4. The values of arithmetic average and standard deviation, and the priority order of Architectural design quality value $(\mathrm{N}=250)$

\begin{tabular}{lllll}
\hline Architectural design quality value & Arithmetic average & $\begin{array}{l}\text { Standard } \\
\text { deviation }\end{array}$ & Relative importance & Priority order \\
\hline $\begin{array}{l}\text { The design interest in the } \\
\text { environment changes (durability) }\end{array}$ & 4.34 & 0.643 & 0.87 & First \\
$\begin{array}{l}\text { Good interior design (benefit) } \\
\text { Aesthetic design }\end{array}$ & 3.56 & 0.832 & 0.71 & Third \\
\hline
\end{tabular}

The results related to the architectural design quality value were as the following: The design interest in the environment changes (durability) was in the first place followed by the aesthetic design in the second place whereas the dimension of good interior design (benefit) was in the third place. All the arithmetic average values were bigger than the standard arithmetic mean (4), with low convergent values for the standard deviation.

\subsection{Testing the Hypotheses}

To test the hypotheses correctness the Multiple Linear Regression analysis has been used. Before running the test, we need to verify that there is no multicollinearity among the independent variables of the entrepreneurial characteristics as it is shown in table (5):

Table 5. The results of (VIF) test to verify the non-existence of multicollinearity among the independent variable dimensions

\begin{tabular}{lll}
\hline Entrepreneurial characteristics & (VIF) & Tolerance \\
\hline The need for achievement & 3.558 & .281 \\
Self-confidence & 4.053 & .247 \\
Take the initiative & 3.876 & .258 \\
Independence and responsibility & 4.538 & .133 \\
Willingness to take risks & 4.689 & .176 \\
Experience & 3.038 & .329 \\
\hline
\end{tabular}

From the results we see that there is no multicollinearity between the entrepreneurial characteristics dimensions. This is confirmed through the values of (VIF) coefficient where all these values were less than the critical value of (5). Based on the aforementioned, we can measure the impact of entrepreneurial characteristics on the architectural design quality value.

4.5.1 Testing the Main Hypothesis

There is no statistically significant effect with the value of $(\alpha=0.05)$ for the entrepreneurial characteristics on the architectural design quality value.

To test the correctness of the main hypothesis, first we should test its sub-hypotheses as the following:

\subsubsection{The First Sub-Hypothesis}

There is no impact of statistical significance with a value of $(\alpha=0.05)$ for the entrepreneurial characteristics on the value of the design interest in the environment changes (durability).

To test the first sub-hypothesis we used the multiple linear regression analysis. Before applying the test, we verified the validity of the model we have as it is shown in table (6). 
Table 6. Analyzing the regression variance in order to test the validity of the multiple linear regression model to measure the impact of entrepreneurial characteristics on the level of the design interest in the environment changes (durability)

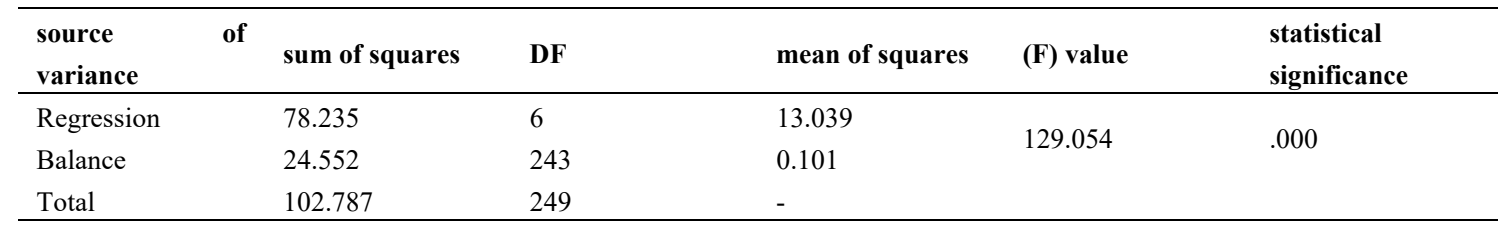

The results in table $(6)$ show that the calculated value of $(\mathrm{F}=129.054)$ is bigger than the $(\mathrm{F})$ tvalue $(2.10)$. The value of statistical significance (0.000) is less than $\mathrm{Sig}$. $(\alpha=0.05)$. This means that the multiple linear regression model is valid; moreover, there is an impact for the entrepreneurial characteristics on the level of design interest in the environment changes (durability). Based on this, we can use the multiple linear regression analysis to measure this impact. Table (7) shows the results of the multiple linear regression analysis.

Table 7. The results of the multiple linear regression analysis to measure the impact of the entrepreneurial characteristics on the level of design interest in the environment changes (durability)

\begin{tabular}{|c|c|c|c|c|}
\hline $\begin{array}{l}\text { Entrepreneurial } \\
\text { characteristics }\end{array}$ & $\begin{array}{l}\text { Regression coefficients } \\
(\beta)\end{array}$ & (t) value & $\begin{array}{l}\text { Statistical } \\
\text { significance }\end{array}$ & (BETA) coefficients \\
\hline $\mathrm{T}$ & -.199 & -1.077 & .282 & \\
\hline The need for achievement & -.015 & -.230 & .818 & -.014 \\
\hline Self-confidence & .291 & .641 & .000 & .263 \\
\hline Take the initiative & .048 & 4.160 & .522 & .040 \\
\hline $\begin{array}{l}\text { Independence } \\
\text { responsibility }\end{array}$ & -.051 & -.493 & .623 & -.042 \\
\hline Willingness to take risks & .407 & 5.065 & .000 & .379 \\
\hline Experience & .354 & 6.422 & .000 & .351 \\
\hline $\begin{array}{l}\text { Multiple correlation coefficient } \\
\text { (R) }\end{array}$ & 0.872 & & & \\
\hline$\left(\mathrm{R}^{2}\right)$ & 0.761 & & & \\
\hline
\end{tabular}

Each of (the need for achievement, take the initiative, and independence and responsibility)has been excluded due to their weak impact on the level of design interest in the environment changes (durability). This has been confirmed through their statistical significance values $(0.818,0.522$, and 0.623$)$ which are bigger than the Sig. ( $\alpha$ $=0.05)$.

The results in table (7) show the statistical significance reliability of regression coefficients $(\beta)$ for each of (self-confidence, willingness to take risks and experience). Based on this, there is an impact of statistical significance at the Sig. $(\alpha=0.05)$ for these dimensions. This has been supported by the (t) value; moreover, the statistical significance value (0.000) is less than the Sig. level $(\alpha=0.05)$. Based on this, we refuse the opposite of the first sub-hypothesis and we accept it as it is, which means that there is an impact for the entrepreneurial characteristics on the level of design interest in the environment changes (durability).

The value of $\left(\mathrm{R}^{2}\right)$ equals $(0.761)$ shows that (self-confidence, willingness to take risks and experience) interpret $(76.1 \%)$ of the changes that affects the value of design interest in the environment changes (durability), whereas the remaining percentage $(23.9 \%)$ it is attributed to other variables that weren't part of the multiple linear regression model.

The values of (BETA) coefficients indicate the impact of entrepreneurial characteristics represented in (self-confidence, willingness to take risks, and experience) on the value of design interest in the environment changes (durability).

The results of the first sub-hypothesis indicated that there is an impact of statistical significance at the Sig. $(\alpha=$ 0.05) of the entrepreneurial characteristics (self-confidence, willingness to take risks, and experience) on the value of design interest in the environment changes (durability). It is worth to mention that (the willingness to take risks) has the highest impact on the value of design interest in the environment changes (durability), as for the strength of $(\beta)$ was $(379$. 


\subsubsection{The Second Sub-Hypothesis}

There is no impact of statistical significance with a value of $(\alpha=0.05)$ for the entrepreneurial characteristics on the value of good interior design (benefit).

To test the second sub-hypothesis we used the multiple linear regression analysis. Before applying the test, we verified the validity of the model we have as it is shown in table (8).

Table 8. Analyzing the regression variance in order to test the validity of the multiple linear regression model to measure the impact of entrepreneurial characteristics on the value of good interior design

\begin{tabular}{llllll}
\hline Source of variance & Sum of squares & DF & Mean of squares & (F) value & $\begin{array}{l}\text { statistical } \\
\text { significance }\end{array}$ \\
\hline Regression & 15.997 & 6 & 2.666 & 4.146 & .001 \\
Balance & 156.258 & 243 & .643 & & \\
Total & 172.255 & 249 & & \\
\hline
\end{tabular}

The results in table (9) show that the (F) value (4.146) is bigger than the $t$ value of $(\mathrm{F})$ which equals $(2.10)$; moreover, the statistical significance $(0.000)$ is less than the Sig. value $(\alpha=0.05)$. This means that the multiple linear regression model is valid; moreover, the entrepreneurial characteristics have an effect on the value of good interior design (benefit). Based on this, we can use the multiple linear regression analysis to measure this effect. Table (9) shows the results of the multiple linear regression analysis.

Table 9. The results of multiple linear regression analysis to measure the effect of entrepreneurial characteristics on the value of good interior design (benefit)

\begin{tabular}{|c|c|c|c|c|}
\hline $\begin{array}{l}\text { Entrepreneurial } \\
\text { characteristics }\end{array}$ & $\begin{array}{l}\text { Regression coefficients } \\
\text { ( } \beta)\end{array}$ & (t) value & $\begin{array}{l}\text { Statistical } \\
\text { significance }\end{array}$ & (BETA) coefficients \\
\hline $\mathrm{J}$ & 2.378 & 5.093 & .000 & \\
\hline The need for achievement & -.312 & -1.859 & .064 & -.214 \\
\hline Self-confidence & .256 & 1.449 & .149 & .178 \\
\hline Take the initiative & .315 & 1.660 & .098 & .200 \\
\hline $\begin{array}{l}\text { Independence } \\
\text { responsibility }\end{array}$ & -.065 & -.245 & .806 & -.041 \\
\hline Willingness to take risks & -.299 & -1.475 & .141 & -.215 \\
\hline Experience & .379 & 2.724 & .007 & .290 \\
\hline $\begin{array}{l}\text { Multiple correlation coefficient } \\
\text { (R) }\end{array}$ & .305 & & & \\
\hline$\left(\mathrm{R}^{2}\right)$ & .093 & & & \\
\hline
\end{tabular}

Each of (the need for achievement, take the initiative, independence and responsibility, and willingness to take risks) has been excluded due to their weak effect on the value of good interior design (benefit). This has been confirmed through their statistical significance values $(0.064,0.0149,0.098,0.806$ and 0.14$)$ which are bigger than the Sig. $(\alpha=0.05)$.

The results in table (9) show the statistical significance reliability for the regression coefficients $(\beta)$ for both characteristics (take the initiative and the willingness to take risks). Based on this, there is an effect of statistical significance at Sig. $(\alpha=0.05)$ of experience. This has been supported by the $(\mathrm{t})$ value; moreover, the statistical significance value $(0.000)$ is less than Sig. $(\alpha=0.05)$. Based on this, we refuse the opposite of the second sub-hypothesis and we accept it as it is, which means that the entrepreneurial characteristics have an effect on the value of good interior design (benefit).

The value of $\left(\mathrm{R}^{2}\right)$ equals $(0.093)$ shows that (experience) interprets $(9.3 \%)$ of the changes that affect the value of good interior design (benefit), whereas the remaining percentage (92.7\%) it is attributed to other variables that weren't part of the multiple linear regression model.

The values of (BETA) coefficients indicate the effect of the entrepreneurial characteristics represented in (experience) on the value of good interior design (benefit). 
The results of the second sub-hypothesis indicated that there is an effect of statistical significance at Sig. $(\alpha=$ 0.05 ) of the entrepreneurial characteristics (experience) on the value of good interior design (benefit).

\subsubsection{The Third Sub-Hypothesis}

There is no effect of statistical significance with a value of $(\alpha=0.05)$ for the entrepreneurial characteristics on the value of the aesthetic design.

To test the third sub-hypothesis we used the multiple linear regression analysis. Before applying the test, we verified the validity of the model we have as it is shown in table (10).

Table 10. Analyzing the regression variance in order to test the validity of the multiple linear regression model to measure the impact of entrepreneurial characteristics on the value of the aesthetic design

\begin{tabular}{llllll}
\hline Source of variance & Sum of squares & DF & Mean of squares & (F) value & $\begin{array}{l}\text { statistical } \\
\text { significance }\end{array}$ \\
\hline Regression & 14.934 & 6 & 2.489 & 3.457 & .003 \\
Balance & 174.944 & 243 & .720 & & \\
Total & 189.878 & 249 & & & \\
\hline
\end{tabular}

The results in table (10) show that the $(\mathrm{F})$ value (3.457) is bigger than the t value of $(\mathrm{F})$ which equals $(2.10)$; moreover, the statistical significance $(0.000)$ is less than the Sig. value $(\alpha=0.05)$. This means that the multiple linear regression model is valid; moreover, the entrepreneurial characteristics have an effect on the value of the aesthetic design. Based on this, we can use the multiple linear regression analysis to measure this effect. Table (11) shows the results of the multiple linear regression analysis.

Table 11. The results of multiple linear regression analysis to measure the effect of entrepreneurial characteristics on the value of aesthetic design

\begin{tabular}{|c|c|c|c|c|}
\hline $\begin{array}{l}\text { Entrepreneurial } \\
\text { characteristics }\end{array}$ & $\begin{array}{l}\text { Regression coefficients } \\
\text { ( } \beta)\end{array}$ & (t) value & $\begin{array}{l}\text { Statistical } \\
\text { significance }\end{array}$ & (BETA) coefficients \\
\hline $\mathrm{J}$ & 3.350 & 6.782 & .000 & \\
\hline The need for achievement & -.067 & -.377 & .706 & .103 \\
\hline Self-confidence & .155 & .831 & .407 & .316 \\
\hline Take the initiative & .523 & 2.603 & .010 & .072 \\
\hline $\begin{array}{l}\text { Independence } \\
\text { responsibility }\end{array}$ & .119 & .426 & .671 & -.341 \\
\hline Willingness to take risks & -.499 & -2.322 & .021 & -.104 \\
\hline Experience & -.143 & -.972 & .332 & \\
\hline $\begin{array}{l}\text { Multiple correlation coefficient } \\
\text { (R) }\end{array}$ & 0.250 & & & \\
\hline$\left(\mathrm{R}^{2}\right)$ & 0.079 & & & \\
\hline
\end{tabular}

Each of (the need for achievement, self-confidence, independence and responsibility, and experience) has been excluded due to their weak effect on the value of aesthetic design. This has been confirmed through their statistical significance values $(0.0706,0.407,0.671$ and 0.332$)$ which are bigger than the Sig. $(\alpha=0.05)$.

The results in table (11) show the statistical significance reliability for the regression coefficients $(\beta)$ for both characteristics (take the initiative and the willingness to take risks). Based on this, there is an effect of statistical significance at Sig. $(\alpha=0.05)$ for each of (take the initiative and the willingness to take risks). This has been supported by the (t) value; moreover, the statistical significance value (0.000) is less than Sig. $(\alpha=0.05)$. Based on this, we refuse the opposite of the second sub-hypothesis and we accept it as it is, which means that the entrepreneurial characteristics have an effect on the value of aesthetic design.

The value of $\left(\mathrm{R}^{2}\right)$ equals $(0.079)$ shows that (take the initiative and the willingness to take risks) interpret $(7.9 \%)$ of the changes that affect the value of aesthetic design, whereas the remaining percentage $(92.1 \%)$ is attributed to other variables that weren't part of the multiple linear regression model.

The values of (BETA) coefficients indicate the effect of the entrepreneurial characteristics represented in (take 
the initiative and the willingness to take risks) on the value of aesthetic design.

The results of the third sub-hypothesis indicated that there is an effect of statistical significance at Sig. $(\alpha=0.05)$ of the entrepreneurial characteristics (take the initiative and the willingness to take risks) on the value of aesthetic design.

\subsection{Testing the Main Hypothesis}

There is no statistically significant effect with the value of $(\alpha=0.05)$ for the entrepreneurial characteristics on the architectural design quality value.

To test the main hypothesis we used the multiple linear regression analysis. Before applying the test, we verified the validity of the model we have as it is shown in table (12).

Table 12. Analyzing the regression variance in order to test the validity of the multiple linear regression model to measure the impact of entrepreneurial characteristics on the value of architectural design quality

\begin{tabular}{llllll}
\hline Source of variance & Sum of squares & DF & Mean of squares & (F) value & $\begin{array}{l}\text { statistical } \\
\text { significance }\end{array}$ \\
\hline Regression & 13.325 & 6 & 2.221 & 5.701 & $.000^{\mathrm{b}}$ \\
Balance & 94.670 & 243 & .390 & & \\
Total & 107.995 & 249 & & & \\
\hline
\end{tabular}

The results in table (12) show that the (F) value (5.701) is bigger than the $t$ value of (F) which equals (2.10); moreover, the statistical significance $(0.000)$ is less than the Sig. value $(\alpha=0.05)$. This means that the multiple linear regression model is valid; moreover, the entrepreneurial characteristics have an effect on the value of architectural design quality. Based on this, we can use the multiple linear regression analysis to measure this effect. Table (13) shows the results of the multiple linear regression analysis.

Table 13. The results of multiple linear regression analysis to measure the effect of entrepreneurial characteristics on the value of architectural design quality

\begin{tabular}{|c|c|c|c|c|}
\hline $\begin{array}{l}\text { Entrepreneurial } \\
\text { characteristics }\end{array}$ & $\begin{array}{l}\text { Regression coefficients } \\
\text { ( } \beta)\end{array}$ & (t) value & $\begin{array}{l}\text { Statistical } \\
\text { significance }\end{array}$ & (BETA) coefficients \\
\hline $\mathrm{J}$ & 2.198 & 6.049 & .000 & \\
\hline The need for achievement & -.152 & -1.161 & .247 & -.131 \\
\hline Self-confidence & .224 & 1.631 & .104 & .197 \\
\hline Take the initiative & .338 & 2.290 & .023 & .271 \\
\hline $\begin{array}{l}\text { Independence } \quad \text { and } \\
\text { responsibility }\end{array}$ & .010 & .048 & .961 & .008 \\
\hline Willingness to take risks & -.224 & -1.416 & .158 & -.203 \\
\hline Experience & .169 & 1.564 & .119 & .164 \\
\hline $\begin{array}{l}\text { Multiple correlation coefficient } \\
\text { (R) }\end{array}$ & 0.351 & & & \\
\hline$\left(\mathrm{R}^{2}\right)$ & 0.123 & & & \\
\hline
\end{tabular}

Each of (the need for achievement, self-confidence, independence and responsibility, willingness to take risks, and experience) has been excluded due to their weak effect on the value of architectural design quality. This has been confirmed through their statistical significance values which are bigger than the Sig. $(\alpha=0.05)$.

The results in table (13) show the statistical significance reliability for the regression coefficients $(\beta)$ for the characteristic of (take the initiative). Based on this, there is an effect of statistical significance at Sig. $(\alpha=0.05)$ for this characteristic. This has been supported by the $(t)$ value; moreover, the statistical significance value $(0.000)$ is less than Sig. $(\alpha=0.05)$. Based on this, we refuse the opposite of the main hypothesis and we accept it as it is, which means that the entrepreneurial characteristics have an effect on the value of architectural design quality.

The results in table (13) show that $\left(\mathrm{R}^{2}\right)$ equals $(0.123)$ which indicates that the characteristic of (take the initiative) interpret (12.3\%) of the changes that affect the value of architectural design quality. 


\section{Results Discussion}

Discussing the results aim to connect those results with the study questions and objectives on one hand and to see the level of the study agreement or disagreement with previous studies in the light of a descriptive analytical approach on the other hand. The discussion includes showing the level of interest in the entrepreneurial characteristics and the architectural design quality. Then, verifying to which level the study hypotheses can be adopted as possible solutions, as well as the interpreting efficiency of the used regression models.

\section{-The level of interest in the entrepreneurial characteristics}

The study sample engineers' opinions were close to each other; moreover, they were of high importance. This indicates the high level of awareness that the engineers have toward the characteristics of (take the initiative, independence and responsibility, the need for achievement, the willingness to take risks, and self-confidence). All form a qualitative frame that enables engineers to do their entrepreneurial roles in fulfilling their missions and try to invest their creativity and readiness to deal with project management risks. This has been supported by the entrepreneurial characteristics convergence in importance and sequence when it comes to the standard deviation low values.

Abd Al-wahhab, (2015) study showed that the entrepreneurial characteristics are highly obtainable by those who own small businesses. As it includes the level of interest inexperience, the need of achievement, self-confidence, independence and responsibility, and take the initiative and experience. There was a difference in the sequence but it indicates the same level of interest in general.

This has been confirmed through the results of (Olawale\& Francis, 2011) study, (Kamal \&Sathiyakala, 2013) study, (Khalid \& Mohammad, 2013) study, (Al-Umari, \&Nasir 2011) study, (Sultan, 2011) study, and (Qais, d.t). They all highlighted the importance of entrepreneurial characteristics in different organizations as being the reason of success and business survival.

\section{-The architectural design quality value:}

The study sample engineers' opinions highly focused on the value of design interest in the environment changes (durability). The highest percentage of their interest was related to the value of aesthetic design and the good interior design (benefit). They had the same sequence and relative importance. The values of standard deviation were low; showing the limited possibility of the engineers' responses diversion from the values of these responses means. This also shows that the architectural design quality has a great level of engineers' attention as for being one of the planned and accomplished businesses.

These results cope with the Greater Amman Municipality's departments and directorates especially when it comes to the architectural dimension and aesthetic design.

The study results harmonize with (Jarrar, 2013) study results that show how the value of architectural design quality is the outcome of the interest in aesthetic design, good interior design (benefit) and the design interest in the environment changes (durability). They also emphasize the importance of the buildings aesthetic dimension as being an un separated part of the architectural design quality value dimensions. In addition to what is mentioned earlier, the result of (Afifi'setal. 2016) shows the importance of the development quality of the design standards.

\section{Discussing the tested hypotheses results}

\subsection{The First Sub-Hypothesis}

The results of analyzing the regression variance proved the reliability of the multiple linear regression model to measure the impact of entrepreneurial characteristics on the value of design interest in the environment changes (durability). This reflects a preliminary acceptance of the hypothesis. The results show that there is a statistically significance effect at Sig. ( $\alpha=0.05)$ for each of (self-confidence, willingness to take risks, and experience) on the value of design interest in the environment changes (durability), whereas the effect of the other characteristics was limited. This results in rejecting the opposite of the first sub-hypothesis and partially accepting it as it is. Not neglecting that (self-confidence, willingness to take risks and experience) interpret (76.1\%) of the possible changes that affect the value of the design interest in the environment changes (durability).

\subsection{The Second Sub-Hypothesis}

The results of analyzing the regression variance proved the reliability of the multiple linear regression model to measure the impact of entrepreneurial characteristics on the value of good interior design (benefit). This means a partial acceptance of the hypothesis. The results show that there is a statistically significance effect at the level of Sig. $(\alpha=0.05)$ for experience and the $\mathrm{J}$ value of good interior design (benefit). The effect of other characteristics 
was limited and insignificant. This means, rejecting the opposite of the hypothesis and partially accepting it as it is. Not neglecting that experience and the $\mathrm{j}$ value interpret $(9.3 \%)$ of the possible changes that affect the good interior design value (benefit).

\subsection{The Thirds Sub-Hypothesis}

The results of analyzing the regression variance proved the reliability of the multiple linear regression model to measure the impact of entrepreneurial characteristics on the value of aesthetic design. This shows a partial acceptance of the hypothesis. The results show that there is a statistically significance effect at the level of Sig. $(\alpha=0.05)$ for (take the initiative and the willingness to take risks) on the value of aesthetic design. The effect of other characteristics was limited and insignificant. This means, rejecting the opposite of the hypothesis and partially accepting it as it is. Not neglecting that (take the initiative and the willingness to take risks) interpret $(7.9 \%)$ of the possible changes that affect the aesthetic design value.

\subsection{The Main Hypothesis}

The results of analyzing the regression variance proved the reliability of the multiple linear regression model to measure the impact of entrepreneurial characteristics on the value of architectural design quality. This shows a partial acceptance of the main hypothesis. The results show that there is a statistically significance effect at the level of Sig. $(\alpha=0.05)$ for the characteristic (take the initiative) on the value of architectural design quality. The effect of other characteristics was limited and insignificant. This means, rejecting the opposite of the main hypothesis and partially accepting it as it is. Not neglecting that (take the initiative)interpret $(12.3 \%)$ of the possible changes that affect the architectural design quality.

\section{Conclusions and Recommendations}

\subsection{Conclusions}

1-The level of engineers' interest in the entrepreneurial characteristics was high and convergent in sequence and significance. This shows the activeness of the engineering mind and the balanced entrepreneurial characteristics that distinguish it.

2- The value of architectural design quality was remarkable wholly and partially. It reflected the entrepreneurial characteristics of engineers and their remarkable role in managing and accomplishing the projects of the Greater Amman Municipality. This was shown through their distinctive interest toward the dimensions of architectural design quality.

3- Accepting the study main and sub hypotheses depending on the results of regression variance analysis. This allows the possibility to interpret the potential changes in the value of architectural design quality, the value of the design interest in the environment changes (durability), the value of good interior design (benefit) and the value of aesthetic design, by the significance of the entrepreneurial characteristics that have been proved by the study results.

4- The significance of self-confidence, the willingness to take risks and experience contribution in interpreting (76.1\%) of the possible changes in the value of the design interest in the environment changes (durability), whereas the contribution of other entrepreneurial characteristics was limited and insignificant.

5- The significance of experience and J value in interpreting (9.3\%) of the possible changes in the value of good interior design (benefit), whereas the contribution of other entrepreneurial characteristics was limited and insignificant.

6- The significance of taking the initiative and willingness to take risks in interpreting (7.9\%) of the possible changes in the value of aesthetic design, whereas the contribution of other entrepreneurial characteristics was limited and insignificant.

7- The significance of the characteristic of taking the initiative in interpreting (12.3\%) of the value of architectural design quality, whereas the contribution of other entrepreneurial characteristics was limited and insignificant.

\subsection{Recommendations}

1- Applying on deepening the awareness of the entrepreneurial characteristics' knowledge of engineers and all the human resources in the Greater Amman Municipality's departments and directorates, also sustaining the sustainability of this knowledge, taking into account the interconnection among them.

2- Giving the architectural design quality value the priority in the engineers' minds, directorates and project departments in which they work; moreover, giving the same priority to its dimensions; the design interest in the 
environment changes (durability), the good interior design (benefit) and the aesthetic design, in order to make it part of the inclusive knowledge of human resources and the Greater Amman Municipality's departments and directorates. Maximizing its value, totally or partially, depends on the availability of the needed awareness and basics that guarantee its environmental, economic and social sustainability.

3- The importance of benefitting from the e-business network system which contributes in achieving balance between the awareness of the entrepreneurial characteristics and the knowledge of the architectural design quality value in the Greater Amman Municipality, to be the key of realizing recognition and maximizing the added economic value as a result.

4- Calling researchers to test the study idea, related to measuring the effect of entrepreneurial characteristics in maximizing the architectural design quality value in the governmental organizations of Jordan. Those which offer public services that would be of distinguished quality in the future.

\section{References}

Abd Al-Wahhab, M. (2015).The Effect of Entrepreneurs on the Success of Small Businesses in the Medical Equipment Supply Organizations in Jordan, Master Thesis (not published), business school, Amman Arab University, Jordan.

Afifi, M. K., Sa'd, I. S.,\& Al-Umari, S. A. A. (2016).Developing the Educational Design Quality Standards for E-learning Courses at Dammam University. Educational Sciences, 1(43).

Al-Umari, G., Nasir, M. J. (2011).Measuring the Entrepreneurship Characteristics for Post Graduate Students in Business Administration and its Impact on Entrepreneurship - Comparative Study. Damascus University Journal of Economic and Legal Sciences, 4(27).

Jarrar, R. M. (2013). The Impact of Architectural Design Quality in Achieving the Competitive Advantage (Exploratory study over a sample of the architectural companies in Amman city), Master Thesis (not published), business school, Middle East University, Jordan.

Kamal,A. K., \& Sathiyakala, J. (2013).Impact of entrepreneurial characteristics on the organizational development of the small business entrepreneurs. Industrial Engineering Letter, 6(3).

Khalid, A. D., \& Mohammed, I. M. (2013).Entrepreneurial characteristics of undergraduate students in deteriorated economies (the case of Gaza Strip) Dirasat. Administrative Sciences, 2(40).

Olawale, F., \&Francis, A. (2011).The impact of firm and entrepreneurial characteristics on access to debt finance by SMEs in King Williams' Town. South Africa International Journal of Business and Management, $8(6)$.

Qais, I. H. (2013). The Role of Entrepreneurial Characteristics in Strengthening the Organizational Commitment, an exploratory study over a sample of CEOs in the Public Company for Electrical Industries. AL GHAREE for Economics and Administration Sciences.

Sultan, S. M. S. (2011). The Availability of Entrepreneurial Characteristics and their Relation with Some Personal Changes: Applied Study on Bachelor Students in Business Administration at the University of the South West Bank. IUG Journal of Economics and Business, 2(24), 102-123.

\section{Copyrights}

Copyright for this article is retained by the author(s), with first publication rights granted to the journal.

This is an open-access article distributed under the terms and conditions of the Creative Commons Attribution license (http://creativecommons.org/licenses/by/4.0/). 